\title{
INFLUENCE OF EDUCATION ON THE INVOLVEMENT OF INHABITANTS IN THE COMMUNITY AFFAIRS - IMPLICATION FOR THE SOCIAL CAPITAL
}

\author{
Beata Będzik, $\mathrm{PhD}^{1}$; Sylwia Gołąb, $\mathrm{PhD}^{2}$ \\ Faculty of Economics, West Pomeranian University of Technology Szczecin
}

\begin{abstract}
The aim of paper is to present the level of respondents involvement in the commune affairs. The results of the analyses presented in this paper come from surveys conducted using a questionnaire survey among residents of rural communes in the West Pomeranian Voivodeship. After rejecting incomplete and/or illogical questionnaires, 2,409 respondents were qualified for the analysis. The results confirmed the relationship between social capital and involvement of inhabitants in the community affairs. Verification of the existence of a relationship between the involvement in the commune affairs (social capital component) and the education of the respondents was verified. The research results indicate the diversity of involvement in level of education groups. The respondents with a minimum level of secondary education noted a positive average level of involvement, which means that they showed more interest in commune matters and willingness to get involved in them. The highest level of involvement was noted in the group of people with post-secondary education. Respondents with basic vocational and elementary and gymnasial education more often showed lack of involvement in the commune's affairs, and thus they recorded negative average results of engagement.
\end{abstract}

Keywords: education, involvement, social capital

JEL code: R200

\section{INTRODUCTION}

The most discussed category in the last two decades is social capital and its role in stimulating social and economic development. It results from the pressure on continuous economic growth, improvement of welfare, change in the status quo, according to the rule more is better. And the existing funds generating socio-economic development have ceased to be enough, but also justify diversification in the pace of development of economies. The efforts undertaken by researchers to identify sources in development disparities have led to the 'discovery' of soft factors as generators of progress in highly developed countries. Among them, the most important role was assigned to social capital, and its integral component is involvement in the affairs of the municipality. Research on the level of involvement of a given community in the municipality's matters is important, because this involvement reveals the community's equipment in social capital and its potential.

${ }^{1}$ Corresponding author: Żołnierska 47, 71-210 Szczecin, Poland, beata.bedzik@zut.pl, +4891 4496994

${ }^{2}$ Corresponding author: Żołnierska 47, 71-210 Szczecin, Poland, sylwia.golab@zut.pl, +4891 4496919 


\section{THEORETICAL BACKGROUND}

Although the importance of ties, cooperation and trust has been noticed for a long time, the concept of social capital did not find its place in science until the 20th century. The first mention of social capital in today's understanding is attributed to Hanifan (1916) in the subject literature. In his work from 1916, he defined the term social capital describing it through the prism of 'kindness, community, mutual compassion and social coexistence between a group of people and families forming a social unit.' At that time, however, this concept was not noticed and appreciated. In the 1960 s, this term was referred to in the work of sociologists and political scientists, but the definitions formulated by Bourdieu $(1980,1986)$ and Putnam (1995) and Coleman (1990) are among the most commonly cited in the literature on the subject. Bourdieu $(1980,1986)$ defined social capital as the sum of real or potential resources that belong to an individual or group due to having a permanent, more or less institutionalized network of relationships, knowledge, mutual recognition or belonging to a group characterized by diverse properties, but also integrated by long-lasting and useful networks. According to Coleman (1990), social capital is 'a set of resources rooted in family relationships and in the social organization of a given community.' $\mathrm{He}$ identified it with the feature of a social structure that supports specific actors' actions undertaken within this structure. Putnam (1995) defined social capital through the prism of such features of a society organization as trust, norms and connections that can increase the efficiency of society by facilitating coordinated actions. He believed that the important, though insufficient for its creation, feature of social capital is trust and shared values. It was Putnam's work that gave rise to widespread interest in this term.

In the field of economic sciences, the concept of social capital is part of the institutional framework. From its perspective, social capital means more or less formalized institutional links that are external and constitute the existence of a state. These institutions are a carrier of social knowledge and trust, reduce transaction costs, increase the level of security when making decisions in conditions of uncertainty, and organize relationships between people (Węziak-Białowolska, 2010).

As noted by Pajakk (2001), 'it is not the accumulated material resources that are the decisive reason for success, but people, their entrepreneurship, the tendency to self-organize and cooperate, the ability to select a group of leaders who enjoy recognition and respect. So, human and social capital is really the foundation of local development.' Therefore, commitment is important because it translates into various forms of activity, but also a sense of responsibility for the common good. Tyszkowa (1990) identifies social activity with the personality trait manifested in readiness to deal with social problems and perform tasks for other people and groups, but also with a set of certain behaviours of the individual, serving the purpose of its striving to influence the environment. This indicates a significant impact of involvement in shaping the quality of life of a given community. As Mantey (2015) emphasizes, 'residents are increasingly appearing as experts in matters that directly affect them. They are encouraged to participate in activities initiating cooperation between them, involved in the decision-making process or motivated to be active for the benefit of the public. Being involved translates into a sense of community and overall - more social trust. All this serves to build an authentic local community, concerned about their living environment.' The effects of these activities and the importance of commitment can also be seen on the formal and legal level introducing the category of participatory budget (civic), which essence is the involvement of the local community.

\section{MATERIALS AND METHODS}

The results presented in the article present a fragment of broader social capital surveys carried out in 2013 and constitute an attempt to search for determinants of social capital at the local level. Due to the relationship between social capital and socio-economic development indicated in the literature, and its average lower level in rural areas, the research was carried out in rural communes. On the other hand, the specificity of social capital as a poorly perceptible 
category in studies of a broad, e.g. national, range, and susceptible to local conditions has led to the limitation of research and focusing them on the local level. The selection of the sample was purposeful and included only the residents of West Pomeranian rural communes, with the overwhelming share of young people due to the long perspective of creating social capital and a large share of respondents with at least secondary education. The research covered all rural communes of the West Pomeranian Voivodeship choosing the number of respondents from each commune so that the sample was representative in terms of the number of inhabitants. The West Pomeranian Voivodeship was selected for research because of the unfavourable situation of rural areas shaped by state-owned farms, which resulted in high local unemployment. Another determinant of the selection of the research space is the low ratio of West Pomeranian social capital in the institutional dimension (Janc, 2009), which in comparison with the results of IPA (Institute of Public Affairs) research showing a negative relationship between the participatory way of management by local authorities and the number of non-governmental organizations in the commune has led to an attempt to verify this relationship (Olech, 2013). The subjective criteria resulting from the place of residence of the person conducting the research are also significant, which has a significant impact on the possibility of obtaining reliable answers.

The results of the analyses presented in this paper come from surveys conducted using a questionnaire survey among residents of rural communes in the West Pomeranian Voivodeship. After rejecting incomplete and/or illogical questionnaires, 2,409 respondents were qualified for the analysis. Most of the respondents were women (57.95\%). Almost half of the respondents did not exceed 30 years of age.

Due to the limited volumetric framework of this publication, only involvement and social capital were considered. Commitment was analysed through membership in non-governmental organizations, attempts to exert influence or doing something for the commune and activities for the benefit of the local community, but the respondent was able to act for the implementation of common goals as the initiator, the main implementer of the project or the active or passive participant.

The aim of the study is to assess the level of involvement of the residents of West Pomeranian rural municipalities and its dependence on the level of education and the possible implications for future social capital. The following descriptive statistics were used in the study:

- to measure the relationship between selected variables, the Pearson's Chi-Square $\left(\chi^{2}\right)$, independence test was used, which is the most appropriate for the study of dependencies between qualitative variables;

- to estimate the models with one or more explanatory variables, multiple regression was used, which is the most appropriate for the quantitative approach to the relationship between many independent variables (explanatory) and dependent variable (criterial, explanatory).

\section{RESULTS AND DISCUSSION}

The respondents with a minimum level of secondary education noted a positive average level of involvement, which means that they showed more interest in commune matters and willingness to get involved in them (Fig. 1). The highest level of involvement was noted in the group of people with post-secondary education (3.20 with standard deviation 1.96). In the second place, in this respect, there were people with higher education (1.06 with standard deviation 1.70), while the third with secondary education ( 0.38 with standard deviation 1.99). On the other hand, respondents with basic vocational and elementary and gymnasial education more often showed lack of involvement in the commune's affairs, and thus they recorded negative average results of engagement $(-1.02$ and -1.09 with standard deviation 0.38 and 0.63 , respectively).

Next, a regression model for social capital was developed, taking into account one independent variable, namely commitment. Table 1 shows the results of these tests.

The regression results of the dependent variable estimated the following model:

social capital $=-3.5433+2.5314 \cdot$ involvement 


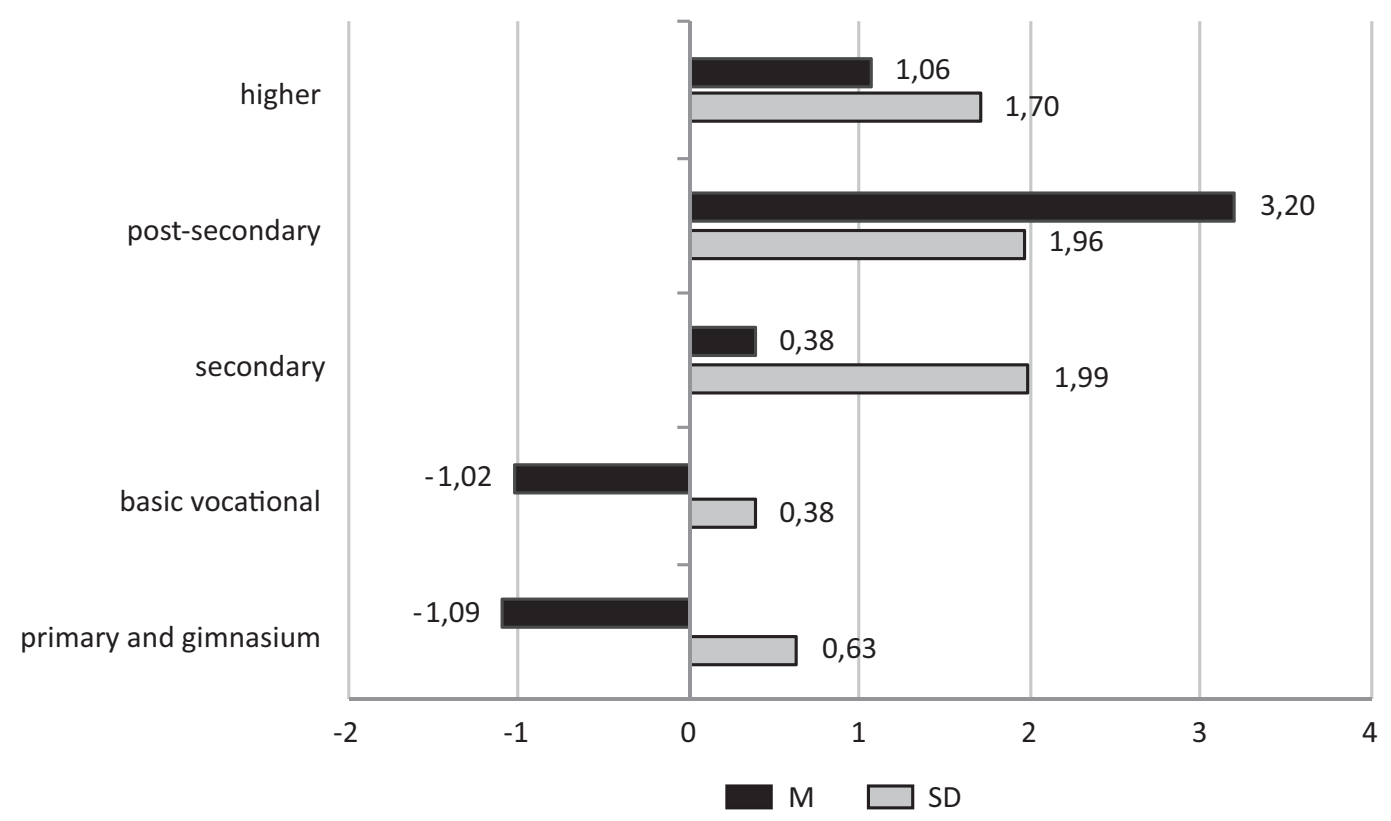

Figure 1. The level of involvement in the division into the education of the respondents (basic descriptive statistics) Source: author's own research outcomes.

Table 1. The results of social capital regression for variable involvement $(N=2,409)$

\begin{tabular}{|l|c|c|c|c|c|c|}
\hline \multirow{3}{*}{ Item } & \multicolumn{5}{|c|}{$\begin{array}{r}\text { regression summary for dependent variable: social capital } \\
\mathrm{R}=0.78830511, \mathrm{R}^{2}=0.62142495, \text { adj. } \mathrm{R}^{2}=0.62126766 \\
\mathrm{~F}(1.2407)=3,951.1, \mathrm{p}<0 \text {, estimate SE: } 3.6113\end{array}$} \\
\cline { 2 - 7 } & \multicolumn{7}{|c|}{$\mathrm{b}^{*}$} & $\mathrm{~b}$ SE & $\mathrm{b}$ & $\mathrm{b}$ SE & $\mathrm{t}(2407)$ & $\mathrm{p}$-value \\
\hline Intercept & $\times$ & $\times$ & $-3,54334$ & 0.073699 & -48.0787 & 0.00 \\
\hline Involvement & 0.788305 & 0.012541 & 2.53135 & 0.040271 & 62.8574 & 0.00 \\
\hline
\end{tabular}

Source: author's own research outcomes.

Such a model shape indicates that if the explanatory variable (involvement) assumes a value of zero, then the explained variable (social capital) assumes a value of around -3.5433 . The increase in commitment per unit means that the explained variable (social capital) assumes a value of around -1.0119 already $(-3.5433+2.5314 \cdot 1)$. This model is good because it explains $62.17 \%$ of the volatility of social capital. Figure 2 illustrates the developed model indicating the dependence of social capital on commitment.

Their personal influence on what is happening in the commune, the respondents with higher (39.95\%) and post-secondary (48.78\%) education most often assessed as rather small, with secondary (43.20\%) and primary education and gymnasium $(58.70 \%)$ - as no impact, and the respondents with basic vocational education in majority did not have an opinion on the subject (74.38\%) - Table 2. The results of the Pearson's Chi-Square test indicate that there was a statistically significant relationship between education and the assessment of personal impact on what is happening in the municipality $(\mathrm{p}<0.001)$.

The respondents with higher education were quite divided in terms of making any attempts to make influence and do something for the commune - most often $(40.89 \%)$ they indicated that they did not un- 


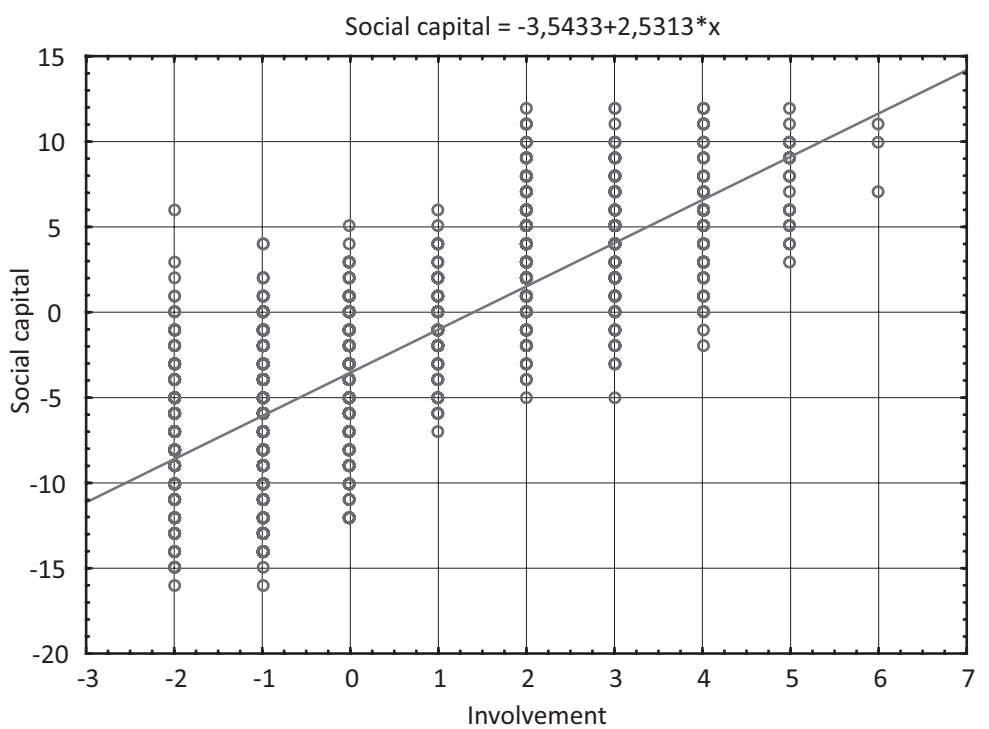

Figure 2. The distribution between commitment and social capital Source: author's own research outcomes.

Table 2. An assessment of the personal impact on what is happening in the commune, broken down into the education of the respondents $(\%)$

\begin{tabular}{|c|c|c|c|c|c|c|}
\hline \multirow[b]{2}{*}{ Opinion } & \multicolumn{6}{|c|}{ Level of education of respondents } \\
\hline & higher & $\begin{array}{c}\text { post- } \\
\text { secondary }\end{array}$ & secondary & $\begin{array}{c}\text { basic } \\
\text { vocational }\end{array}$ & $\begin{array}{l}\text { primary and } \\
\text { gimnasium }\end{array}$ & $\begin{array}{c}\text { Chi-square } \\
\text { value }\end{array}$ \\
\hline Yes, I have an large impact & 5.26 & 0.00 & 0.00 & 0.00 & 0.00 & \multirow{6}{*}{$\begin{array}{c}X^{2}=431.66 \\
d f=16 \\
p=0.000\end{array}$} \\
\hline Yes, I have an impact & 5.72 & 51.22 & 12.64 & 0.00 & 0.00 & \\
\hline Rather small influence & 39.95 & 48.78 & 24.64 & 9.09 & 28.26 & \\
\hline No impact & 30.96 & 0.00 & 43.20 & 16.53 & 58.70 & \\
\hline Don't know & 18.11 & 0.00 & 19.52 & 74.38 & 13.04 & \\
\hline Total & 100.00 & 100.00 & 100.00 & 100.00 & 100.00 & \\
\hline
\end{tabular}

Source: author's own research outcomes.

dertake such activities, but almost as many people from this group (40.07\%) undertook such activities (Table 3). Among people with post-secondary education, the overwhelming majority have ever made such attempts (90.24\%). In the studied groups with secondary, primary and lower secondary education, it was most often indicated that such attempts never took place (43.52 and 76.09, respectively), whereas people with basic vocational education mostly did not have knowledge on this subject $(80.17 \%)$. The results of the Pearson's Chi-Square test indicate that there was a statistically significant relationship between education and making attempts to do something for the municipality $(\mathrm{p}<0.001)$.

People with higher and post-secondary education most often played the role of an active participant in activities for the benefit of the local community (42.52 and 56.10\%, respectively), while those with secondary and primary education as well as gymnasium - a passive participant (36.16 and 67.39\% respectively) - Table 4. Most people with basic vocational education could not unequivocally indicate their role in activities for the benefit of the local community $(82.64 \%)$. The results of the Pearson's Chi-Square 
Proceedings of the 2018 International Scientific Conference 'Economic Sciences for Agribusiness and Rural Economy' No 2, Warsaw, 7-8 June 2018, pp. 280-286

Table 3. Undertaking any attempts to exert influence and do something for the municipality, broken down into the education of the respondents

\begin{tabular}{|c|c|c|c|c|c|c|}
\hline \multirow[b]{2}{*}{ Item } & \multicolumn{6}{|c|}{ Level of education of respondents } \\
\hline & higher & post-secondary & secondary & basic vocational & $\begin{array}{l}\text { primary and } \\
\text { gimnasium }\end{array}$ & $\begin{array}{c}\text { Chi-square } \\
\text { value }\end{array}$ \\
\hline Yes & 40.07 & 90.24 & 33.44 & 0.00 & 0.00 & \multirow{4}{*}{$\begin{array}{c}X^{2}=312.912 \\
d f=8 p=0.000\end{array}$} \\
\hline No & 40.89 & 9.76 & 43.52 & 19.83 & 76.09 & \\
\hline Don't know & 19.04 & 0.00 & 23.04 & 80.17 & 23.91 & \\
\hline Total & 100.00 & 100.00 & 100.00 & 100.00 & 100.00 & \\
\hline
\end{tabular}

Source: author's own research outcomes.

Table 4. Role in activities for the benefit of the local community according to the education of the respondents

\begin{tabular}{|c|c|c|c|c|c|c|}
\hline \multirow[b]{2}{*}{ Role in activities } & \multicolumn{6}{|c|}{ Level of education of respondents } \\
\hline & higher & $\begin{array}{c}\text { post- } \\
\text { secondary }\end{array}$ & secondary & $\begin{array}{c}\text { basic } \\
\text { vocational }\end{array}$ & $\begin{array}{l}\text { primary and } \\
\text { gymnasium }\end{array}$ & $\begin{array}{l}\text { Chi-square } \\
\text { value }\end{array}$ \\
\hline Initiator of the project & 11.10 & 14.63 & 4.64 & 0.00 & 0.00 & \multirow{6}{*}{$\begin{array}{c}\mathrm{X}^{2}=576.386 \mathrm{df} \\
=16 \\
p=0.000\end{array}$} \\
\hline Main project implementer & 14.49 & 19.51 & 7.84 & 0.00 & 0.00 & \\
\hline Active participant & 42.52 & 56.10 & 27.52 & 0.00 & 0.00 & \\
\hline Passive participant & 26.40 & 0.00 & 36.16 & 17.36 & 67.39 & \\
\hline Don’t know & 5.49 & 9.76 & 23.84 & 82.64 & 32.61 & \\
\hline Total & 100.00 & 100.00 & 100.00 & 100.00 & 100.00 & \\
\hline
\end{tabular}

Source: author's own research outcomes.

test indicate that there was a statistically significant relationship between education and Role in activities for the benefit of the local community $(p<0.001)$.

\section{CONCLUSIONS}

The presented results confirmed the positive relationship between commitment and social capital. They also indicated determination of involvement in the issues of the commune with the level of education. It results, as research shows, from the feeling of less educated respondents, little influence on the environment, which limits their activity in this sphere, and at the same time legitimizes their passivity. This study supports the contention that the level of the education has the potential to meaningfully support development of key element of social capital - involvement of inhabitants in the community affairs - that might, in turn, spur civic and political engagement, with the consequences for the level of social capital, in the future.

Due to the fact that social capital forms such components as trust, cooperation, civic participation, its effects are most visible at the local level, which implies the necessity to conduct research in the local dimension as well. The presented research results give the opportunity to look at and assess the level of community involvement at the local level. This is an important contribution to expanding knowledge in this area, as commonly available statistical data are usually aggregated and do not capture the specificity of the given environment, which is extremely important in the case of the discussed category, which is affected by local conditions. This research is part of the assessment of an important component of social capital, which is commitment, giving the opportunity to use the results in building local development concepts and strategies. 


\section{REFERENCES}

1. Bourdieu, P. (1980). Le capital social. Actes de la Recherche en Sciences Sociales, 31, pp. 2-3.

2. Bourdieu, P. (1986). The Forms of Capital. In: Richardson, J.G. (ed.) Handbook of Theory and Research for the Sociology of Education. Greenwood Press, New York, pp. 241-258.

3. Coleman, J.S. (1990). Foundations of Social Theory. Harvard University Press, Cambridge MA.

4. Hanifan, L.J. (1916). The Rural School Community Center. Annals of the American Academy of Political and Social Science, 67, pp. 130-138.

5. Janc, K. (2009). Zróżnicowanie przestrzenne kapitału ludzkiego i społecznego w Polsce [Spatial differentiation of human and social capital in Poland]. Instytut Geografii i Rozwoju Regionalnego Uniwersytetu Wrocławskiego, Wrocław.

6. Mantey, D. (2015). Zaangażowanie a zaufanie czyli wybrane aspekty kapitału społecznego na przykładzie podwarszawskiej gminy Podkowa Leśna [Commitment and trust, or selected aspects of social capital, based on the example of the Podkowa Leśna commune]. Mazowsze Studia Regionalne. Analizy i Studia, 16, pp. 109-124.
7. Olech, A. (2013). Partycypacja publiczna w Polsce. Diagnoza i rekomendacje [Public participation in Poland. Diagnosis and recommendations]. Analizy i Opinie, 3, pp. 1-24.

8. Pająk, K. (2001). Samorząd terytorialny a rozwój lokalny w Polsce w procesie transformacji [Local government and local development in the process of transformation in Poland]. Wyższa Szkoła Zarządzania i Bankowości w Poznaniu, Poznań.

9. Putnam, R. (1995). Demokracja w działaniu. Tradycje obywatelskie we współczesnych Włoszech [Making Democracy Work. Civic Traditions in Modern Italy]. Społeczny Instytut Wydawniczy Znak, Kraków-Warszawa.

10. Tyszkowa, M. (1990). Aktywność i działalność dzieci i młodzieży [Activity of children and youth]. WSiP, Warszawa.

11. Węziak-Białowolska, D. (2010). Kapitał społeczny w Polsce - propozycja pomiaru i wyniki [Social Capital in Poland - Measurement Proposal and Outcomes]. Zeszyty Naukowe Instytutu Statystyki i Demografii SGH, 4, pp. 4-30. 